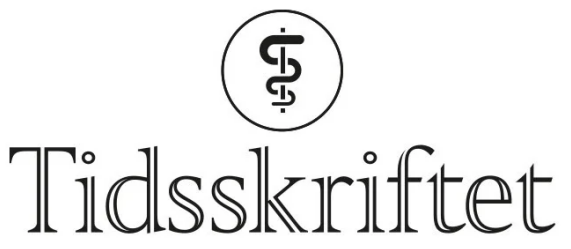

DEN NORSKE LEGEFORENING

\title{
Pris til Randi Ulberg for klinisk psykiatrisk forskning
}

Legelivet

Gunn Marit Seberg

Email: gunn.marit.seberg@legeforeningen.no

Tidsskriftet

Randi Ulberg (f. 1962), overlege ved Klinikk psykisk helse og rusbehandling ved Sykehuset i Vestfold, er tildelt pris fra «Solveig og Johan P. Sommers stiftelse til fremme av fremragende klinisk psykiatrisk forskning» for 2014.

Stiftelsen deler årlig ut en pris for et publisert arbeid som representerer nyvinnende, klinikknær og fremragende klinisk psykiatrisk forskning.

Ulberg mottar prisen for artikkelen Women respond more favorably to transference intervention than men; a randomized study of long-term effects som i 2012 ble publisert i Journal of Nervous and Mental Disease.

Artikkelen viser at kvinnelige pasienter har mer nytte enn menn av intervensjoner fra legen.

- Grunnen til at Solveig og Johan P. Sommers stiftelse i år har gitt prisen til Randi Ulberg er fordi mulige forskjeller mellom kjønnene når det gjelder effekt av psykoterapi, er et område som det er forsket lite på. Det er derfor svært viktig at dette undersøkes med gode empiriske metoder og design, sier professor emeritus Lars Weisæth.

- Psykoterapiforskningen ved Universitetet i Oslo har en lang tradisjon. Randi Ulberg tilhører den neste generasjon forskere som er tilknyttet dette forskningsmiljøet, og vi håper prisen vil oppmuntre til videre forskning.

Publisert: 29. april 2014. Tidsskr Nor Legeforen. DOI:10.4045/tidsskr.14.0345

(C) Tidsskrift for Den norske legeforening 2023. Lastet ned fra tidsskriftet.no 26. april 2023. 